\title{
A BRIEF HISTORICAL ACCOUNT OF GLOBAL DATA PRIVACY REGULATIONS AND THE LESSONS FOR MALAYSIA
}

\author{
Md. Toriqul Islam* \\ Mohammad Ershadul Karim** \\ Universiti of Malaya (UM)
}

\begin{abstract}
In this data-driven society, diverse actors always track and monitor our activities and consequently, we are losing our privacy. Therefore, the agenda of privacy and data protection has become one of the hot-button issues in global policies, politics, and business nowadays. Thus, the appeal of understanding privacy is becoming crucial today for not only to the legal scholars but also to the scholars of all other majors and disciplines. Keeping this in view, this article outlines a precise historical account of global data privacy regulations having Malaysian data privacy regime in focus with recent developments in the field.
\end{abstract}

Keywords: Data privacy, privacy in Malaysia, PDPA, GDPR

\section{Introduction}

Privacy has become one of the pressing issues in the contemporary global information economy because of numerous reasons, e.g., the globalization in communication; growing attention on data processing by the government and non-government actors; deliberate data sharing in social media; commercialisation of data; utilisation of cloud computing, and above all, valuing privacy as one of the basic human rights. ${ }^{1}$ Even in this data-driven society, we often share a bulk of our personal data voluntarily while learning, teaching, educating, making business, socializing and so on. Indeed, these compelling realities of data sharing and subsequent severe consequences have made profound the trivial philosophy of 'the right to be let alone'2 affecting the present lifestyle. Therefore, the call for understanding privacy is becoming important day by day regardless of race, sex, gender, nation, region, religion and even area of study.

It is worthy of note that even though privacy has had a long historical root, it has become popular worldwide just after the publication of Warren Brandis's premier work 'the Right to Privacy' in $1890 .{ }^{3}$ Since then onwards, privacy has been recognized in the major national legislation, regional and international legal and human rights instruments and Constitutions of more than 130 countries of the world. ${ }^{4}$ However, the precise objective of this article is to present a brief historical development of the global data privacy regulations and offer several workable recommendations for the Personal Data Protection Act, 2010 of Malaysia (PDPA) to improve the Malaysian privacy regime.

\section{Understanding Privacy}

In the present article, we will be discussing the historical account of the global data privacy regulations, nonetheless, some propositions need to be explained owing to convenience and clarification. There is no definition of the term 'privacy' in the PDPA, and therefore, we would explain the notion quoting from the famous scholars in the field. We would describe the rest of the terminologies based on the interpretation as given in the PDPA. 
Much ink has been spilt in defining the term 'privacy' ${ }^{5}$ and as an abstract, it is not an easy concept, ${ }^{6}$ rather it is full of some fascinating and distinctive features which are not so clearly understood. ${ }^{7}$ Some scholars found privacy as a vague and inadequately defined conception. ${ }^{8}$ To avoid these definitional complications, Ruth Gavison strived to demarcate the domain of privacy using some constituent components. To her, privacy is a notion that consists of three elements, e.g., anonymity, solitude and secrecy. ${ }^{9}$ Westin remarked that privacy encircles the individual, social, regulatory and technological spheres of a nation in the diverse and overlaying ways. ${ }^{10}$

Simply speaking, privacy is explained as a matter of protecting one's intimate spheres from the interference of the other or the outsiders. Of course, due to the accelerated progress and pervasiveness of information technology nowadays, the distinction between private and public domain is, in no way, an easy thing. ${ }^{11}$ Above all, the term 'privacy' incorporates a wide range of issues within its domain, and thus, it appears in the multifaceted denominations, e.g., physical, proprietary, decisional or informational. ${ }^{12}$ Other than the definition of privacy, section 4 of the PDPA defines relevant important terminologies to make the law clear in terms of understanding and application. Among those terminologies, the following are shared for the purpose of the present article.

Personal Data: Personal data implies any information which relates to any identifiable person directly or indirectly in any kind of commercial transactions, or any other information held by a data user as to an individual, including any sensitive data or opinion regarding a data subject but shall not add any information processed by any credit reporting company to carry on a credit reporting business under the Credit Reporting Agencies Act, 2010. ${ }^{13}$

Sensitive Personal data: The sensitive personal data refers to any information relating to the physical or mental health condition of a data subject, including the political, religious and other views thereof. It may include also the commission or the allegation of committing of an offence by a person, or any other personal data which is likely to be determined and published in the Official Gazette by the Minister of Communications and Multimedia from time to time. ${ }^{14}$

Data subject: Data subject signifies a person who is the subject of the personal data, processed either by the processor or the data user. ${ }^{15}$

Processing: The data processing means the collection, storing, holding, recording or conducting any transaction concerning the personal data. ${ }^{16}$

Data processor: Data processor implies an individual, who, except the employee of the data user, deals with the personal data for and on behalf of the data user, but not for personal purposes. ${ }^{17}$

Data User/ Controller: Data users mean and include those who process the personal data of the data subjects alone or jointly with some other persons, or who has the authority or control over the data processing activities but will not incorporate the data processors. ${ }^{18}$

\section{Importance}

Even though in a plain language, history refers to a study of past incidents, particularly in connection with human affairs, ${ }^{19}$ but specifically, it means a sequentially written account of significant events affecting a particular race, nation, organisation or region usually carries a clarification of the causes thereof. ${ }^{20}$ Therefore, to conduct a research on global data privacy regulation from a historical point of view, it is a very relevant question, why privacy is a matter or why it is inevitable? Indeed, privacy is undoubtedly undeniable, as, in the absence of privacy protection provisions, people 
may have to suffer from several irreparable losses, for example, a single health data revelation may cause to wreck of one's marriage, or the news of addiction in alcoholism or drug may be sufficient for losing a job and so on. ${ }^{21}$

To explain the importance of understanding privacy, Alan Westin remarked that the desire for privacy is not limited to humans only, rather every creature essentially searches for privacy in a small-group intimacy. ${ }^{22}$ The ecological studies of Westin exhibit that the scarcity of intimate space may cause huge threats to survival. ${ }^{23}$ In another research, Adam D. Moore finds that in the absence of intimate personal life, the beasts may destroy them, or grossly involve in the suicidal decreases of their population. ${ }^{24}$ Experimenting with mice and slots in the cages, Calhoun notices that a certain proportion of space is inevitable for each species and the lack of which leads to the splitting in the friendly relations and causes ailments, heart failure and raised the blood pressure. ${ }^{25}$ Therefore, we may now plausibly conclude that privacy is valuable, and it is one of the basic requirements of human life, culture and wellbeing like all other creatures.

Indeed, the right to privacy is very crucial to us as we all love to have a private life, and we want to share our correspondence and memories with those only whom we believe. Moreover, in a pure democratic culture, personal liberty includes the autonomy and freedom of the individuals from the unauthorised access of the business, State and non-State actors. ${ }^{26}$ In a networked society, privacy is more valued than any other rights, because in the current days we are to share our valuable personal information to numerous bodies in the course of modern lifestyle; even knowing the vulnerability of our privacy. Therefore, it would be disastrous, if any of these actors' leak, in any way, our sensitive personal data, and these losses will be unthinkable, as most of them are irreparable and admit no substitutes or compensations.

\section{Historical Development}

Although privacy seems to be a recently developed notion, it can be traced back to several ancient codes, e.g., the Greek, Roman, Anglo-Saxon etc. ${ }^{27}$ Indeed, the concept of privacy had long ancient roots in both the anthropological and sociological discourses in term of value and preservation. ${ }^{28}$ Aristotle's demarcation on the publicprivate dichotomy of politics, i.e., the polis and oikos are often identified as the usual reference to privacy. ${ }^{29}$ This public-private construction was also employed to mean the matter of national authority, in contrast, the self-regulation in the description of John Stuart Mill's essay, On Liberty, ${ }^{30}$ and similar justification appears in Locke's 'Second Treatise on Government' too. ${ }^{31}$

The modern perception of privacy is nearly 150 years old only. A 5-sentence long summary of privacy may be as follows: (1) to ensure separate rooms for each one, people began to build internal walls in $1500 \mathrm{AD}$; (2) praying and reading silently had been started as a popular habit since 1215 era; (3) people started using single bed since 1700 era; (4) people have been cautious about the privacy of information since the 1900 s, especially after the publication of Warren and Brandeis' 'the Right to Privacy', and finally, (5) privacy is about to finish again, as it was in the early society. ${ }^{32}$

Westin observes the development of privacy into four different periods, e.g., 1945-60 (first phase); 1961-1979 (second phase); 1980-1989 (third phase), and 19902002 ( last stage). ${ }^{33}$ With Westin's stand, we can add a fifth phase comprising 20032019. Westin termed the period of 1961-79 as the early age of privacy understanding, as the roots of informational privacy were ingrained in this high-tech era. ${ }^{34}$ Whereas, the quarter of 1980-1989 was a comparatively quiet preceding to the storm within which no major changes were taken place about the perception of informational privacy and the society. ${ }^{35}$ The period of 1990-2002 was considered as the most 
important phase, as during the time, privacy has become one of the influential social and political issues in the US and beyond, especially, after the incident of $9 / 11 .^{36}$

Based on Westin, the added fifth phase (2003-2019) may be known as the age of numerous technological breakthroughs including social media, Google and WikiLeaks, and internet of things, etc. when the use of personal data are witnessing an unbelievable extension having unprecedented privacy implications. To apprehend the flow of developments, facts, insights and standards of privacy, it is advisable to go through the ancient and contemporary international instruments on privacy, hence, in the succeeding part of this paper, we will focus on those issues.

\section{Privacy in the Ancient Codes}

In conformity with the philosophy of Aristotle's paternalistic conception, Robert Filmer formulates an analogy between a father and the State arguing that the State should take care of its citizens like a father. ${ }^{37}$ Similarly, being influenced by Aristotle, Robert P. George opined, the law existed to make men virtuous, and there was no distinction between public and private sectors, rather intertwined. This philosophy predominated until the medieval age, ${ }^{38}$ and it is still equally worthwhile to care for the betterment of a large group of people.

Even though the ancient Codes do not hold any binding authority, nevertheless, the principles enumerated in those Codes can be related to the present privacy and data protection issues, particularly in the questions of ownership and responsibilities of data collectors. ${ }^{39}$ There are a series of dogmas in the ancient Codes, for example, the Code of Hammurabi, which included principles containing responsibilities for the data controller. ${ }^{40}$ Likewise, the classic 'Hippocratic Oath' contained the following privacy statement about their patients:

"What I may see or hear in the course of the treatment or even outside of the treatment in regard to the life of men, which on no account one must spread abroad, I will keep to myself, holding such things shameful to be spoken about." 41

Again, Part XIV of the Justinian's Code laid down several principles concerning the obligation toward the privacy and personal data, for example, it declares-

"But he who has received a thing lent for his use is indeed bound to employ his utmost diligence in keeping and preserving it; nor will it suffice that he should take the same care of it, which he was accustomed to taking off his property." 42

\section{Privacy in the Religious Texts}

Privacy is deeply rooted in the religious verses, precepts and rituals too. Even though there is neither any equivalent term nor any provisions prohibiting the privacy intrusion in the Holy Bible, nonetheless, some biblical passages may be explained as the distinctive spheres of privacy. ${ }^{43}$ Milton Konvitz, described, The Holy Bible introduces the feeling of shame in its very outset as a violation of privacy. While eaten the prohibited fruit in the Paradise, Adam and Eve found themselves naked and subsequently, tailored fig leaves into their body as aprons. ${ }^{44}$ Thus, it is evident ideologically that our belief regarding right and wrong, our morals stand in many ways on spiritual command and so in the case of privacy as well. 
On the contrary, the Holy Quran, has incorporated certain specific provisions for privacy and personal life, and respects the value and sanctity of privacy and condemns its invasion harshly. To revere one's privacy, Islam prescribes two folded instructions, i.e., (1) take useful measures for one's privacy, ${ }^{45}$ and (2) instruct not to cross the limits toward other's privacy. ${ }^{46}$ Emphasising the significance of one's right to privacy, the Holy Quran asserts, 'do not spy on one another'; 'do not enter into any houses except your own, unless you get the consent of its occupants. ${ }^{47}$

The Prophet (PBUH) has taught his companions not to access even in one's own residence swiftly or secretly, and if invited to get into the dwelling of another, the invitee should seek the permission before entering into that premises, as directed by the Holy Quran. ${ }^{48}$ Islam prefers to realise privacy even in the family setting as well as ruling out that a grown-up man must seek permission ahead to enter into the residence of other adults. ${ }^{49}$ Even the minors should do the same before his/ her entrance in an adult's residence, at least three times, e.g., sooner than the morning prayer, during putting off clothes at noon, and after the prayer of the night. ${ }^{50}$

Indeed, the protection afforded by Islamic law is much wider than that of the well-established cause of action for defamation in the English legal system. The Islamic law prevents one to defame others, even though the assertion is true. ${ }^{51}$ This is alien to the popular English law, where truth is a defence against any defamatory statement regardless of considering how much embarrassing it might be because of the malicious plan of others. ${ }^{52}$ Thus, all these divine sources of law firmly recognize the right to privacy of the individuals and promote thereof.

\section{Privacy in the National Legal Regimes}

In spite of having long historical roots, privacy seems to be the phenomenon of our time, as Godkin remarks, privacy is manifestly a modern product. ${ }^{53}$ Since the publication of Warren and Brandis, the American Law Schools had started teaching on privacy education, and simultaneously, the US Congress started passing numerous sector-specific privacy laws as well. ${ }^{54}$ Henceforth, there has been a global trend of enacting data privacy legislation in a frequency of regular interval after the post-70s era. As Greenleaf shows, from 1973 to 2016, the global community have passed laws for data protection on an average rate of 2.7 new nations every year. ${ }^{55}$

Though provisions on the protection of some aspects of personal data could be traced in all legal system, the Germans' Hessian Data Protection Act, 1970 was the first regional data protection law in the universe. ${ }^{56}$ Whereas Sweden was the first nation to enact a data privacy law in 1973, and following the trend, France, Germany, Denmark, Austria and Norway passed the data privacy laws in $1978 .{ }^{57}$ Relevantly, Malaysia became the first country in the Southeast Asian region that enacted it's the first law aiming to protect the personal data, the Personal Data Protection Act in 2010, which came into effect in $2013 .^{58}$ To date, a total of 135 countries have enacted data protection laws, and plenty of other nations are yet to enact. ${ }^{59}$

The emergence and historical development of global data privacy regulations have been progressed in the following manner. The philosophical foundation of privacy had rooted in Aristotle's public-private dichotomy; ancient codes, and some religious texts as well. The informational privacy, on the other hand, started with the seminal work of Warren Brandis's 'the Right to Privacy', whereas, the US Supreme Court recognized, for the first time, the Constitutional right to privacy in Griswold $v$. Connecticut ${ }^{60}$ and Roe v. Wade ${ }^{61}$ case, respectively. The United Nations has recognized the right to privacy since 1948 and 1961 respectively through its UDHR, ${ }^{62}$ and ICCPR. ${ }^{63}$ 


\section{Privacy in Malaysia}

\section{Privacy culture}

The perception and value of privacy largely depend on the socio-cultural and religious values of a particular locality, nation and region. Therefore, to comprehend the Malaysian perception of privacy, we should learn the ethnography of Malaysia. Malaysia is a multi-cultural and multi-racial country which is blessed with the Malays, Chinese, Indians and some other indigenous tribes sharing respectively, according to the Government source, $67.4 \%, 24.6 \%, 7.3 \%$ and $0.7 \%$ in the total population. ${ }^{64}$ As per the World Factbook, CIA, USA, the percentage rates are respectively, the Bumiputera $62 \%$ Chinese $20.6 \%$, Indian $5.7 \%$, other $0.8 \%$, and non-citizens $10.3 \% .{ }^{65}$ By all metrics, Malaysia is one of the very few nations which has moderately succeeded in balancing the competing interests among the different ethnic groups. ${ }^{66}$

As one of the basic human values, privacy is not an alien notion in Malaysia, rather underpins the prevailing Malay cultures in terms of personal behaviour and social interactions. According to the Constitution of Malaysia, the State religion is Islam, ${ }^{67}$ and even to become a Malay, a person is required to profess Islam, speak using the Malay language habitually, and comply with the custom of Malay. ${ }^{68}$ In particular, Islamisation of thoughts was firmly started and applied within all 13 states of Malaysia during the era of Dr Mahathir's administration (1981-2003). ${ }^{69}$ Hence, Islam plays a dominant role in Malaysian culture, politics and policies, and so in the case of privacy and, the Malaysian approach to privacy is greatly influenced by Islamic laws. ${ }^{70}$

The influence of Islam and Islamic beliefs on the traditional Malaysian culture has been manifested by many other ancient texts, inter alia, the Bustan alSalatin fi Dhikr al-Awwalinwa al-Akhirin (Boston Sultans in the last two monarchs), (1048-1051 AH/1638-1641 AD) (Malay); Bad 'Khalq al-Samawatwa al-Ard' (The Beginning of the creation of the heavens and earth) (Malay); Akhbar al-Akhirah $f i$ Ahwal al-Qiyamah (The Account of the hereafter and the day of judgement) (1052 AH/1642 AD); Ayn al- 'Alam Qabl 'an Yukhlaq (A writing concerning the earth before creation) (Malay); Hikayat Iskandar Dhulqarnain (Alexander Romance); Tibyan fi Ma'rifat al-Adyan (The 'Explanation of faiths (1052-1054 AH/1642-1644 AD) (Malay) (henceforth Tibyan) and so on. ${ }^{71}$

This pro-Islamic Malay perception of privacy is exposed to housing planning, layout preparation, gender-based space management also so that the daily household-works of women cannot be viewed by men, especially by the outsiders. $^{72}$ The prevailing Malay Budi (etiquette) and Bahasa (language) play a significant role in observing privacy in Malaysia too. The Malaysian Budi and Bahasa teach how to behave inside and outside of the family, convey greetings, enter into the houses, maintain clothes and so on. Meaning that the views of Islam about privacy are deeply embedded in Malay culture. ${ }^{73}$

\section{Privacy Related Notable Cases}

Even though the Constitution of Malaysia recognizes all basic human rights, there are no express provisions for privacy. Additionally, since 2010, there was no single and robust data privacy law in Malaysia, even though there were several isolated provisions of privacy in some general laws of the realm. Therefore, Malaysia witnessed numerous privacy dilemmas over the years because of the lack of specific data privacy legislation. Some notable case studies are as follows: 


\section{a) Example \# 1}

In most parts of the world, the privacy of the celebrities are in stake in all times, and Malaysia is not an exception. In the early 2000s, Malaysian celebrity named Nasha Aziz complained about the intrusion of her privacy because of the installation of CCTV cameras in her apartment which videotaped her daily routine activities, including the footage of her undressing. In that allegation, the accused was sentenced to six months imprisonment by a Magistrate Court in 2004 because of trespassing one's premise illegally and the intrusion of one's privacy. While petitioned against that judgement, the Court of Appeal rejected it considering that the fact is highly intrusive to the actress. ${ }^{74}$

\section{b) Example \# 2}

The non-existence of specific privacy law may lead to irreparable privacy losses. For example, on August 20, 2007, Nurin, an 8-year-old girl was reported missing at night from a Pasar Malam (night market) adjacent to her residence. The case received huge media coverage as her dead body was found within a bag outside the market on September 17, 2007, and the post-mortem report exposed that Nurin was sexually abused to death. Later, two police officers were accused of circulating the post-mortem photos on the internet. Even though, the case was withdrawn against all defendants by a mutual agreement with the victim's father, the disclosure of the distressful photos was undoubtedly a massive disgraceful matter for Nurin's family. ${ }^{75}$

\section{c) Example \# 3}

Maintaining privacy for the public figures is truly a very hard job like the privacy of celebrities as both remain under the lenses all the year-round. In 2008, some sleeping naked photos of a member of the Bukit Lanjan State Assembly were publicly disseminated on the internet by her ex-boyfriend who went on absconding after the occurrence. Consequently, the victim resigned from all of her positions in the party and Government. Subsequently, on request, she withdrew her position and kept herself in all positions. Even though she did not take any legal action against the culprit, the incident seriously breaches her right to privacy. ${ }^{76}$

\section{d) Example \# 4}

At times, punishments can stop the wrongdoer, but, it is dubious whether the punishments can recompense the losses caused to the victims. For example, a hidden cam video sex tape of a high council member of the Malaysian Chinese Association (MCA) was circulated on the internet in 2009. Later, the high council member acknowledged that he was the other person in the video, and accordingly, resigned from all of his positions in the party and the Government. As the incident took place before the enactment of the Data Protection Act (PDPA), 2011, the accused was charged under section 292 of the Penal Code, and eventually, the Data Protection Act (PDPA), 2011 was enacted against these backdrops. ${ }^{77}$

\section{Development of Data Protection Law}

Like the global trends, the perception of privacy has gradually developed in Malaysia. Although the Federal Constitution of Malaysia did not recognise the right to privacy expressly, many other laws of Malaysia recognised this right. ${ }^{78}$ In the past few 
decades, there has been a global trend of enacting comprehensive data privacy law because of the compelling necessities, and so in the case of Malaysia. In this section, we would focus on the gradual development of privacy and data protection issues in Malaysia.

\section{a) First Phase: Legal Recognition of Privacy}

Last few decades, the issue of privacy and data protection have become the buzzwords in many parts of the globe, and so in the case of Malaysia too. Nevertheless, the Federal Constitution of Malaysia did not recognise the right to privacy. ${ }^{79}$ Of course, the right to privacy was recognised in a wide array of the existing laws of Malaysia, e.g., the Births and Death Registration Act $1957 ;{ }^{80}$ the Private Hospitals Regulations 1973; the Penal Code 1976; the Law Reform (Marriage and Divorce) Act $1976 ;{ }^{81}$ the Private Healthcare Facilities and Services Act $1998 ;{ }^{82}$ the Communication and Multimedia (Licensing) Regulations 1999; the Child Act $2001 ;^{83}$ the Credit Reporting Agencies Act, 2010; ${ }^{84}$ and the Financial Services Act $2013,{ }^{85}$ etc.

Furthermore, the right to privacy has been explicitly recognised in the Penal Code, for example, section 509 of the Act renders- "whoever intending to insult the modesty of any person utters any word, makes any sound or gesture, or exhibits any object, intending that such word or sound shall be heard, or that such gesture or object shall be seen by such person, or intrudes upon the privacy of such person, shall be punished with imprisonment for a term which may extend to five years or with fine or with both". Above all, due to the lack of constitutional recognition of privacy, the people of Malaysia were to depend on the interpretation of the courts in the question of privacy right until the PDPA was enacted in 2010.

\section{b) Second Phase: Recognition of Privacy by Court Rulings}

The question of the right to privacy had been raised in many cases in Malaysia, and probably, because of the lack of constitutional recognition, for long, the Malaysian courts did not recognise the right to privacy, even though, later, the courts gave several verdicts favouring this right. For example, in Ultra Dimension Sdn Bhd v Kook Wei Kuan case, ${ }^{86}$ the Malaysian High Court rejected a petition claiming for damages based on the privacy intrusion and breach of confidence. ${ }^{87}$ Even the Court of Appeal took a similar view in Dr Bernadine Malini Martin v. MPH Magazines Sdn Bhd \& Ors (17 May 2010). ${ }^{88}$

Subsequently, the Malaysian judiciary has taken decision promoting the right to privacy, for instance, in Sivarasa Rasiah v Badan Peguam Malaysia \& Anor case, the Federal Court observed that........personal liberty as recognized in Article 5 (1) of the Federal Constitution includes many rights, inter alia, the right to privacy. ${ }^{89}$ Since then, the Federal Court of Malaysia has paved the way to open the door of the right to privacy in Malaysia. ${ }^{90}$

\section{c) Third Phase: Enactment of Data Protection Law}

Nearly two decades ago, the necessity of enacting a data protection law was felt in Malaysia. In 1998, the Secretary-General of the Ministry of Energy, Communications and Multimedia, Datuk Noraizah Abdul Hamid, declared, Malaysia was seeking to enact a comprehensive data protection law following the OECD Guidelines, the EU Directives, UK, Hong Kong and New Zealand models to ensure the secrecy and integrity in the collection, processing and utilization of data transmitted through the electronic network. ${ }^{91}$ 
However, the formal journey of the Personal Data Protection Act of Malaysia was started in 2000, when the country issued a proposed bill in this regard and released it for the public feedback. ${ }^{92}$ Subsequently, a new bill was introduced in 2007, followed by the first reading by 2009, and second and third readings by April 2010. ${ }^{93}$ Later, the PDPA was sent for the Royal assent, and it received the Royal assent on 2 June 2010 and passed by the Federal Parliament of Malaysia on 10 June of the same year, ${ }^{94}$ and finally, the enactment came in to effect on 15 November 2013. ${ }^{95}$

Thus, after waiting a period of more than 10 years since 2000, the Federal Parliament of Malaysia adopted the Personal Data Protection Act, 2010 (Act No. 709), which was the first data protection legislation among the ASEAN nations. ${ }^{96}$ On the same day, the Malaysian policymakers issued and gave effect some other subordinate laws, e.g., Personal Data Protection Regulations; Personal Data Protection (Registration of Data User) Regulations; Personal Data Protection (Fees) Regulations; Personal Data Protection (Class of Data Users) Order, and Appointment of the Personal Data Protection Commissioner. ${ }^{97}$ However, the whole PDPA covers a total of seven key points, for example, the General Principle; the Notice and Choice Principle; the Disclosure Principle; the Security Principle; the Retention Principle; the Data Integrity Principle, and the Access Principle. ${ }^{98}$

\section{Recent Developments}

\section{Major International Legal Instruments}

Contemporary international conventions and declarations hold some sorts of persuasive influence and obligatory legal force to protect the civil and human rights relating to privacy. These instruments offer some basic standards for corporations and governments as well, and as per rule, the endorsers usually comply with the principles mandatorily. ${ }^{99}$ For the sake of convenience, we can divide all major international legal instruments into two subheads, e.g., (i) the United Nations' documents (ii) other international legal instruments.

\section{a) The United Nations' Documents}

Among the United Nations' documents, the notable instruments which focus the right to privacy are, inter alia, (a) the Universal Declaration of Human Rights, 1948 (UDHR); ${ }^{100}$ (b) International Covenant on Civil and Political Rights, 1966 (ICCPR); ${ }^{101}$ (c) the Convention on the Rights of the Child, (1989); ${ }^{102}$ (d) International Convention on the Protection of the Rights of All Migrant Workers and Members of Their Families, $1990 ;{ }^{103}$ (e) UN General Assembly Guidelines Concerning Computerized Personal Data Files, 1990. ${ }^{104}$

As per the principles of international law, the UDHR does not have any direct binding legal effect upon the member states of the United Nations. Of course, over the years, the document has acquired the authority of the customary international legal standards compelling for all nations of the United Nations. ${ }^{105}$ On the other hand, there are total of 172 parties, and 74 signatories to the ICCPR, and among the members, China, ${ }^{106}$ Comoros, ${ }^{107}$ Cuba, ${ }^{108}$ Nauru, ${ }^{109}$ Palau ${ }^{110}$ and Saint Lucia ${ }^{111}$ have signed the Covenant but not ratified. Moreover, there are many other states which are neither the signatories nor the parties to the ICCPR, and Malaysia is one of them. 


\section{b) Other International Legal Instruments}

\section{OECD Guidelines on the Protection of Privacy, 1980}

During the 1970s, globally, the policymakers began to feel the necessity of introducing the global privacy policy standard as the trans-border data flows were increasingly becoming a fact to take into notice. ${ }^{112}$ Even some policymakers apprehended that the data security offered in national regimes were likely to be bypassed in the cross-border data processing activities. ${ }^{113}$ This ground reality created the understanding that certain principles, rules or guidelines were to be farmed and agreed upon at the international arena. ${ }^{114}$ Eventually, two international organizations, e.g., the Organization for Economic Cooperation and Development (OECD), and the Council of Europe had attempted to formulate the guiding principles encompassing privacy for generating harmonized data protection standards. ${ }^{15}$

\section{Revised Privacy Guidelines, 2013}

Notwithstanding the overwhelming attainment, an accord was growing to revise the Guidelines, as Michael Kirby observed, due to the evolution of the internet and world wide web; search engines; social networking sites; location tracking technology; biometrics and other technologies etc., were raising inevitable questions as to the effectiveness of the OECD Guidelines. ${ }^{116}$ Consequently, after conducting a rigorous review process, the OECD adopted a Revised Privacy Guidelines on 9 September 2013. ${ }^{117}$ The Guidelines have had a tremendous track record and influence in the succeeding developments over privacy principles, practices and legislation in diverse nations across the world, e.g., Turkey, Russia, South Africa, Mexico, nations of the APEC region and so on. ${ }^{118}$

\section{Major Regional Legal Instruments}

The right to privacy concerning one's home, correspondence and family life are repeatedly presented in a wide range of regional legal instruments. Howbeit, the major regional international legal instruments are clearly divided into two subclasses, e.g., the non-EU documents, and the EU based documents.

\section{The non-EU legal instruments}

Among the non-EU efforts, the notable legal documents consisting the provisions of data privacy are, among others, the American Declaration of the Rights and Duties of Man, 1948; ${ }^{119}$ the American Convention on Human Rights, $1969 ;{ }^{120}$ the APEC Privacy Framework, 2004, and the ASEAN Human Rights Declaration etc. ${ }^{121}$

\section{The ASEAN Human Rights Declaration}

The Heads of the ASEAN nations adopted the ASEAN Human Rights Declaration (AHRD) on 18 November 2012. ${ }^{122}$ However, both the ASEAN and Commission received mix reactions from both the regional and international entities, such as the UN High Commissioner for Human Rights, the US Department of State, Human Rights Watch, Amnesty International and different civil society groups of the ASEAN region. ${ }^{123}$ Despite criticisms, the Declaration offers a unique normative standard for the state-citizens relationships by upholding the human rights in the region which should not be underestimated. ${ }^{124}$ Among all others, the ASEAN Human Rights 
Declaration has its great utility because of incorporating the privacy provisions. Article 21 of the Declaration, for example, affirms:

"Every person has the right to be free from arbitrary interference with his or her privacy, family, home or correspondence including personal data, or to attacks upon that person's honour and reputation. Every person has the right $t$ o the protection of the law against such interference or attacks". ${ }^{125}$

\section{The EU legal instruments}

It is well settled that regionally, the EU plays very impressive roles in establishing the comprehensive privacy regulations challenging even the US dominance in the sphere. ${ }^{126}$ Historically, the EU data protection legal framework can be shown by four distinct periods, such as (1) national data protection regimes (19701980); (2) internationalisation (1980-1981); (3) national implementation (1982-1994); (4) European harmonisation (1995-2016/ 2018). ${ }^{127}$ Albeit, the major European efforts to ensure the privacy rights, are among others, the European Convention on Human Rights and Fundamental Freedoms, 1950; ${ }^{128}$ the Convention of Council of Europe, 1981; ${ }^{129}$ Directive 95/46/EC, 1995, and the General Data Protection Regulation, (GDPR) 2018.

\section{The General Data Protection Regulation (GDPR) and its Implications}

Among the EU legal instruments, the last three documents, e.g., the Convention of Council of Europe, the Directive 95/46/EC, and the General Data Protection Regulation, especially, the GDPR carry much more importance, which launched a novel epoch on 25 May 2018 by offering numerous changes in many areas, e.g., technology, advertising, medicine, banking and so on. ${ }^{130}$ Generally, the GDPR does not apply to the countries outside the European Economic Area (EEA) unless they process the personal data of the EU residents being within or outside the EU. Like all other non-EEA states, the Malaysian are not directly bound to comply with the provisions of the GDPR, but it may apply against any controller or processor processing personal data of the EU residents and so in the case of Malaysia. ${ }^{131}$

Indeed, the GDPR has considerable impacts on Malaysian business, legal and policy affairs, because, in terms of the GDP, Malaysia is the 3rd-biggest economy in the ASEAN and 3rd-major business partner of the EU in the region. Besides, Malaysia became the EU's 23rd global biggest business partner in goods shared an amount of $€$ 39.8 billion in $2018 .^{132}$ Thus, the implications of GDPR cannot be ignored in the context of Malaysia.

In addition, as per the decision of European Commission, ${ }^{133}$ if the data privacy law of a nation does not comply with the GDPR, then they are deemed to have an inadequate privacy regime. Currently, Andorra, Argentina, Guernsey, Isle of Man, Israel, Jersey, New Zealand, Switzerland and Uruguay have obtained the complete adequacy decision, and partial findings of adequacy were granted for Japan, Canada and the USA. ${ }^{134}$. Recently, the EC is working on adequacy decision about South Korea, ${ }^{135}$ Malaysia is neither in the list nor in any consideration. 


\section{Lessons for Malaysia}

Even though once the Malaysian PDPA, 2010 was identified as a different new taste in the growing data protection laws in the Asia Pacific region, ${ }^{136}$ but there are several shortcomings in the PDPA in comparison with the GDPR. ${ }^{137}$ Hence, Malaysia needs to amend the PDPA in compliance with the GDPR to maintain the smooth business relationships with the EU by obtaining the adequacy decision, and avoid the bitter consequence for non-compliance to GDPR. Undoubtedly, the PDPA has many positive features of a robust data protection law, nonetheless, to obtain the adequacy certificate from the EU, it shall have to take appropriate measures in the following areas:

i. Application: Unlike the GDPR, the PDPA applies to the processing of personal data regarding any commercial transaction only which may lead to confusion about an activity as to whether it is commercial or not. ${ }^{138}$ It restricts the material scope of the legislation too, and therefore, this part should be amended pursuant to the GDPR to widen the ambit of the Act. Additionally, the PDPA shall not apply against any State or the Federal Government of Malaysia, and to such data which is processed outside Malaysia, unless further processed in Malaysia. ${ }^{139}$

ii. Consent: As a lawful basis of data processing, both the GDPR and PDPA incorporate, among others, the data subject's consent. Though article 4 (11) of the GDPR explicitly explains about consent, the PDPA, on the other hand, does not include any explanation about it.

iii. Appointment of DPO: The GDPR requires some institutions processing especially the large-scale personal data to appoint a data protection officer to act either as a data controller or a data processor. There is no such requirement of appointment of any data protection officer in the PDPA, 2010.

iv. Data breach notification: The GDPR asserts that the data controllers will have to report as to the data breach incidents to the supervisory body within 72 hours. The data controllers are also duty-bound to report the data subjects about such breach if it is likely to cause a high risk to them. ${ }^{140}$ In PDPA, there is neither any requirement for the data controllers to notify the supervising authority nor the data subjects concerning the data breach incidents.

v. The right to be forgotten: The right to be forgotten or right to the erasure of personal data of the data subject is allowed in the GDPR, ${ }^{141}$ but not in the PDPA. PDPA, on the contrary, allows the data subject to withdraw his consent in writing, and upon getting such notice, the data users would stop the processing of personal data.

vi. Data portability: Whenever the data processing is justified because of consent of the data subjects, or the processing is essential for the continuation of a contract, or when processing goes on by automated manner, then, the data subject can either receive or transfer the personal data to another controller in a commonly used, structured or machine-readable format. It is worthy of note that this is purely a unique addition of the GDPR and there was no equivalent right in the previous Directives. The PDPA does not have any right like this at all. 
vii. Enforcement: The GDPR imposes only the revenue-based fine, the minimum amount of which is $€ 10$ million or $2 \%$ of annual global turnover, ${ }^{142}$ whereas the maximum is up to $€ 20$ million or $4 \%$ of annual worldwide turnover, whichever is higher. ${ }^{143}$ Additionally, it allows the filing of suits for the capture of profits, injunctions, and the perpetual prohibition on data processing. ${ }^{144}$ The PDPA incorporates, on the contrary, both fines and imprisonment, the sanctions are minimum fines not exceeding fifty thousand ringgit or not more than six years imprisonment or both. ${ }^{145}$ Whereas, the maximum punishments are fines up to five hundred thousand ringgit or not more than three years imprisonment or both. ${ }^{146}$

viii. Pseudonymized data: Pseudonymisation is another new technique of processing of the processing of personal data under the GDPR, which means the processing of personal data without connecting them to any data subject. ${ }^{147}$ By the application of this method, the data users can process the personal data without attaching them to any specific data subject. For better protection of personal data of the individuals, the GDPR incorporates this tool so that the data users could process the personal data without identifying the data subjects. ${ }^{148}$ It benefits both the data subjects and the data users, but, the PDPA does not contain any provision like this.

\section{Conclusion}

Privacy is one of the pressing dilemmas in the contemporary world, and Malaysia is not an exception. In response to this challenge, Malaysia, like many other nations, enacted the PDPA in 2010. No doubt the PDPA is a robust and comprehensive data protection legislation but requires certain amendments to meet the challenges of the day. In this paper, the notable shortcomings and loopholes of the PDPA are discussed. But these are not exhaustive, as there may be many more issues that Malaysia may need to take into consideration for removing the deficiencies of the PDPA. However, in the updating projects, the Malaysian PDPA should address the current shortcomings by extending the definition of 'personal data' to non-commercial transactions; widening the scopes to cover the Government activities; expanding the territorial scope to include both the national and international processors and controllers; adding an explanation to the meaning of consent; mandating the appointment of the data protection officers for regular monitoring of the data subjects' rights; inserting some other provisions like the data breach notification, the right to be forgotten, data portability and so on.

\section{Note}

* Md. Toriqul Islam (toriqul@siswa.um.edu.my) is an Assistant Professor, Department of Law and Justice, Bangladesh University of Business and Technology (BUBT), and PhD Candidate, Faculty of Law, University of Malaya (UM), Malaysia.

** Dr. Mohammad Ershadul Karim (ershadulkarim@um.edu.my) is a Senior Lecturer, Faculty of Law, University of Malaya (UM), Malaysia.

${ }^{1}$ Christopher Kuner, Fred H. Cate, Christopher Millard, and Dan Jerker B. Svantesson, "The Extraterritoriality of Data Privacy Laws: An Explosive Issue yet to Detonate" International Data Privacy Law, Vol. 3, No. 3, May 2013, pp. 147-148.

${ }^{2}$ Thomas McIntyre Cooley, A Treatise on the Law of Torts or the Wrongs which Arise Independent of Contract, Chicago: Callaghan and Company, 1879, p. 29. 
${ }^{3}$ Warren and Brandeis, "The Right to Privacy" Harvard Law Review, Vol. 4, No. 5, December 1890, p. 193.

4 "What Is Privacy?" Privacy International, Privacy International, available at privacyinternational.org/explainer/56/what-privacy, accessed 2 September 2019.

5 Judith Jarvis Thomson, "The Right to Privacy" Philosophy and Public Affairs, Vol. 4, No. 4, Summer 1975, pp. 295-314.

${ }^{6}$ Lategan FA, "Enforcing Privacy on the Internet" Ph.D. Thesis, University of Johannesburg, South Africa, 2002, p. 33.

${ }^{7}$ Pepperell, K. C., "Privacy, Rights, and Education" Ph.D. Thesis, The Ohio State University, 1990, p. 1.

${ }^{8}$ Richard A. Posner, "The Right of Privacy" The American Economic Review, Vol. 71, No. 2, May 1981, pp. 405-409.

9 Ruth Gavison, "Privacy and the Limits of Law" The Yale Law Journal, Vol. 89, No. 3, January 1980, pp. 421-471.

${ }^{10}$ Alan F. Westin, "Social and Political Dimensions of Privacy" Journal of Social Issues, Vol. 59, No. 2, 2003, pp. 431-453.

11 Baldauf, Matthias, Schahram Dustdar, and Florian Rosenberg, "A Survey on Context-Aware Systems" International Journal of Ad Hoc and Ubiquitous Computing, Vol. 2, No. 4, 2007, p. 263.

12 Anita L. Allen, "Privacy-as-Data Control: Conceptual, Practical, and Moral Limits of the Paradigm” Connecticut Law Review, Vol. 32, 2000, p. 861.

${ }^{13}$ Personal Data Protection Act, 2010 (PDPA), (Act 709), Part I (Interpretation), section 2.

${ }^{14}$ Ibid.

${ }^{15}$ Ibid. Note: Data subject is a popular terminology used in place of 'data user' as referred in PDPA.

${ }^{16}$ Ibid.

17 Ibid.

18 Ibid.

${ }^{19}$ Dictionary, Oxford English, “Lexico” Oxford: Oxford University Press, 2018.

${ }^{20}$ Merriam-Webster, Inc., Merriam-Webster's Dictionary of Synonyms, Merriam-Webster, 1984, p. 403.

${ }^{21}$ James Rachels, Why Privacy Is Important, Belmont, CA, USA: Wadsworth Publ. Co. 1985, pp. 194-201.

${ }^{22}$ Alan F. Westin, Privacy and Freedom, New York: Athenum. 1967, pp. xvi, 487.

${ }^{23}$ Ibid., p. 17.

${ }^{24}$ Adam D. Moore, "Privacy: Its Meaning and Value" American Philosophical Quarterly, Vol. 40, No. 3, July 2003, pp. 215-227.

25 John B.Calhoun, "The Study of Wild Animals Under Controlled Conditions" Annals of the New York Academy of Sciences, Vol. 51, No. 6, November 1950, pp. 1113-1122.

${ }^{26}$ David Loukidelis, "Privacy Information Basics: The Importance of Privacy" Submission of the Office of the Information and Privacy Commissioner for British Columbia, Canada, 2008, pp. 1-52.

${ }^{27}$ Samuel H. Hofstadter, Samuel Dennis Warren, and Louis Dembitz Brandeis, The Development of the Right of Privacy in New York, New York: Grosby Press, 1954; Roscoe Pound, "Interests of Personality [Concluded]" Harvard Law Review, Vol. 28, No. 15, 1915, p. 445.

28 Judith DeCew, "Privacy" The Stanford Encyclopaedia of Philosophy, Spring 2018, Edward N. Zalta (ed.), available at https://plato.stanford.edu/archives/spr2018/entries/privacy/, accessed 3 September 2019.

${ }^{29}$ Ibid.

${ }^{30}$ John Stuart Mill, On Liberty, London: The Electric Book Company Ltd, 1859, p. 1-162.

${ }^{31}$ John Locke, Second Treatise of Government: An Essay Concerning the True Original, Extent and End of Civil Government, Alexandria: Library of Alexandria 1956, p. 1-167.

${ }^{32}$ Greg Ferenstein, "The Birth and Death of Privacy: 3,000 Years of History Told through 46 Images" The Ferenstein Wire, 2015, available at https://medium.com/the-ferenstein-wire/the-birth-and-deathof-privacy-3-000-years-of-history-in-50-images-614c26059e, accessed 3 September 2019.

${ }^{33}$ Westin, "Social and Political Dimensions of Privacy", p. 8.

${ }^{34}$ Ibid.

${ }^{35}$ Ibid., p. 13.

36 Ibid., 16.

${ }^{37}$ Robert Filmer, Patriarcha and Other Political Works, New Jersey: Transaction Publishers, 1949, p. 326.

${ }^{38}$ Robert P. George, Making Men Moral: Civil Liberties and Public Morality, Oxford: Oxford University Press, 1993, p. 1. Most prominently, Aquinas took this idea. See Thomas Aquinas, Summa Theologiae, 1917. I-II q.91 a1. 
${ }^{39}$ Ray William London, "Comparative Data Protection and Security Law: A Critical Evaluation of Legal Standards" Ph.D. Thesis, University of South Africa, 2013, p. 138.

${ }^{40}$ Ibid., p. 136-138.

41 "Hippocratic Oath - Classical Version" Health Sciences Library, McMaster University, available at https://hslmcmaster.libguides.com/c.php?g=306726\&p=2044095, accessed 3 September 2019.

42 "Code of Justinian, (Codex Justinianus)" Part XIV, available at http://thelatinlibrary.com/law/institutes.html accessed 3 September 2019.

${ }^{43}$ The search was not much comprehensive rather limited to the following versions of the Bible: the King James Version, the American Standard Version, the New International Version, the Revised Standard Version, the Young's Literal Translation and the New American Standard Bible.

${ }^{44}$ Milton R. Konvitz, "Privacy and the Law: A Philosophical Prelude" Law and Contemporary Problems, Vol. 31, No. 2, Privacy, Spring, 1966, pp. 272- 280. See, also, Hurriyah El Islamy, "Privacy as Freedom of Private Life: The Re-Examination of the Concept, The Scope and Its Analysis and Comparison with the Law of Confidence in the United Kingdom and Malaysia" Ph.D. Thesis, University of Strathclyde, 2006, p. 14.

${ }^{45}$ Al-Qur'an, Surah An-Nur [24:27].

${ }^{46}$ See, Sahih Bukhari, Volume 8, Book 73, Number 9 2. See also Book 80, Number 717. See also, Sahih Muslim, Book 3, Chapter 16: 667-8.

${ }^{47}$ Al-Qur'an, Surah Al-Ahzab [33:53].

${ }^{48}$ Ibid., Surah An-Nur [24:27].

${ }^{49}$ Ibid., Surah Al-Ahzab [33:53].

${ }^{50}$ Ibid., Surah An-Nur [24:59 and 24:58].

${ }^{51}$ Ibid., Surah Al-Hujurat [49:12].

${ }^{52}$ Ibid., Surah Al-Humazah [104:1].

${ }^{53}$ Edward L. Godkin, "The Rights of the Citizen, Iv—-to His Own Reputation" Scribner's Magazine, Vol. 8, No. 1, 1890, pp. 58-67.

${ }^{54}$ The Federal Trade Commission Act, 1914, the Video Privacy Protection Act, 1988, the Children's Online Privacy Protection Act, 1990, the Driver's Privacy Protection Act, 1994, and California Consumer Privacy Act, 2018. Even though there is no explicit recognition of privacy in the US Constitution, in numerous case, the US Supreme Court observed that the US Constitution has implicitly granted the right to privacy of the individuals against the intrusion form the governmental activities by the First Amendment, Third Amendment, Fourth Amendment, and the Fifth Amendment.

${ }^{55}$ Graham Greenleaf, "Countries with Data Privacy Laws-by Year 1973-2016 (Tables)" Privacy Laws \& Business International Report, 2017, p. 18.

${ }^{56}$ Justice Michael D. Kirby, "Transborder Data Flows and the Basic Rules of Data Privacy" Stanford Journal of International Law, Vol. 16, 1980, p. 39

${ }^{57}$ Nick Platten, "Background to and History of the Directive", in D Bainbridge, EC Data Protection Directive, London: Butterworths,1996, p. 14

${ }^{58}$ Hanis Zainal, "Govt to Amend Act to Boost Data Protection" The Star Online, available at https://www.thestar.com.my/news/nation/2019/03/19/govt-to-amend-act-to-boost-data-protection, accessed 3 September 2019

${ }^{59}$ Graham Greenleaf, "Global Data Privacy Laws 2019: 132 National Laws \& Many Bills" Privacy Laws \& Business International Report Vol. 157, 2019, 14.

${ }^{60} 381$ U.S. 479, 85 S. Ct. 1678, 14 L. Ed. 2d 510 (1965).

${ }^{61} 410$ U.S. 113, 93 S. Ct. 705, 35 L. Ed. $2 d 147$ (1973).

${ }^{62}$ UN General Assembly, "Universal Declaration of Human Rights" UN General Assembly Resolutions No. A/RES/217(III) A, 1948, article, 12.

${ }^{63}$ UN General Assembly, "International Covenant on Civil and Political Rights" UN General Assembly Resolutions No. A/RES/2200(XXI)A-C, 1966, article, 17.

64 Department of Statistics, Malaysia Official Portal, available at https://www.dosm.gov.my/v1/index.php?r=column/cone\&menu_id=eHcwazFVZ11OQ2U2c1JzSINE clFuQT09, accessed 3 September 2019.

65 Central Intelligence Agency, The World Factbook, available at https://www.cia.gov/library/publications/the-world-factbook/geos/my.html, accessed 3 September 2019.

${ }^{66}$ Mirzan Mahathir and Fazillrwan, "Malaysia's Role in Asian Regional Cooperation: A Look at Foreign Policy Themes" Asia Pacific Review, Vol. 14, No. 2, 2007, pp. 97-111.

${ }^{67}$ The Federal Constitution of Malaysia, 1957, article 3.

${ }^{68}$ Ibid., article 160.

${ }^{69}$ R. Sivaperegasam P. Rajanthiran, "The Impact of Art. 121 (1a) 1988 on Art. 11-the Freedom of Religion in the Federal Constitution of Malaysia: The Apostasy Case of Lina Joy" SEJARAH: 
Journal of the Department of History, Vol. 26, No. 1, June 2017, p. 117.

${ }^{70}$ Zainal Kling "The Malay Family: Beliefs and Realities" Journal of Comparative Family Studies, Vol. 26, No. 1, Spring 1995, p. 60.

${ }^{71}$ Hamzah N and Denisova T, "Elements of Islamic History in the Works of Nur Al-Din Al-Raniri" Journal of Al-Tamaddun, Vol. 12, No. 1, 2017, pp. 93.

72 George Michell, Architecture of the Islamic World, London: Thames and Hudson, 1987. See also, M.R. Mohamad Tajuddin, "Essays on Architecture" Universiti Teknologi Malaysia, Johor, Vol 1, 1997.

${ }^{73}$ Hashim, Ahmad Hariza, Zaiton Abdul Rahim, Sharifah Norazizan Syed Abdul Rashid, and Nurizan Yahaya. "Visual privacy and family intimacy: a case study of Malay inhabitants living in two-storey low-cost terrace housing", Environment and Planning B: Planning and Design 33, No. 2, 2006, pp. 301-318.

74 "Nasha Spy Camera Case: Supervisor Loses Appeal" The Star Online, available at https://www.thestar.com.my/news/nation/2008/10/06/nasha-spy-camera-case-supervisor-losesappeal/, accessed 3 September 2019. See also “Judges Send Man Who Fixed Spy Camera in Model's Home to Prison" The Star Online, available at https://www.thestar.com.my/news/nation/2008/10/07/judges-send-man-who-fixed-spy-camera-inmodels-home-to-prison, accessed 3 September 2019.

75 M Mageswari "Nurin's Dad Reaches out-of-Court Settlement in Negligence Suit against Government" The Star Online, available at https://www.thestar.com.my/news/nation/2010/11/29/nurins-dad-reaches-outofcourt-settlement-innegligence-suit-against-govt/, accessed 3 September 2019.

76 Christina Tan "Eli Wong Back at Work" The Star Online, available at https://www.thestar.com.my/news/nation/2009/04/16/eli-wong-back-at-work-update, accessed 3 September 2019. See also, "Elizabeth Wong Just Wants to Get Back to Work" The Star Online, available at https://www.thestar.com.my/news/nation/2009/04/17/elizabeth-wong-just-wants-to-getback-to-work, accessed 3 September 2019.

77 See "Police Launch Probe, Warn of Penalties for Having Video" The Star Online, available at https://www.thestar.com.my/news/nation/2008/01/02/police-launch-probe-warn-of-penalties-forhaving-video, accessed 3 September 2019.

${ }^{78}$ Munir, Abu Bakar, Yasin, Siti Hajar Mohd and Md Ershadul Karim, Data Protection Law in Asia, Hong Kong: Sweet \& Maxwell, 2018, p. 209.

${ }^{79}$ Ibid.

${ }^{80}$ Act No. 299, Malaysia, section 4 (4) (b).

${ }^{81}$ Act No. 164, Malaysia.

${ }^{82}$ Act No. 586, Malaysia, section 107 (2) (z) (ii).

${ }^{83}$ Act No. 611, Malaysia, section 12 (2).

${ }^{84}$ Act No. 710, Malaysia, section 30 (5) (c).

${ }^{85}$ Act No. 758, Malaysia.

86 (2004) 2004 CLJ 5285.

${ }^{87}$ Munir, Abu Bakar and Yasin Siti Hajar Mohd, Personal data protection in Malaysia: Law and practice, Sweet \& Maxwell, 2010, p. 13.

88 (2006) 2006 CLJ 21117.

${ }^{89}$ Munir and Yasin, Personal data protection in Malaysia: Law and practice, pp. 14-15.

${ }^{90}$ Munir, Yasin, and Karim, Data Protection Law in Asia, p. 212.

91 Munir, Abu Bakar and Yasin, Siti Hajar Mohd, Privacy and Data Protection: A Comparative Analysis with Special Reference to Malaysian Proposed Law, Sweet \& Maxwell Asia, 2002, p. 173.

92 Pointon, Leo Desmond and Phuoc, Jeong Chun, Personal Data Protection: Cases and Commentary with Applied Syari'ah Principles, CLJ Publication, 2012, p. 1.

${ }^{93}$ Ibid.

94 Ibid.

${ }^{95}$ Munir, Yasin, and Karim, Data Protection Law in Asia, p. 209.

${ }^{96}$ Ibid.

${ }^{97}$ Ibid.

${ }^{98}$ PDPA, Part II, Division 1.

${ }^{99}$ Ray William London, “Comparative Data Protection and Security Law” p. 138.

100 Article 12.

101 Article 17.

102 Article 16.

103 Article 14 and 15.

${ }^{104}$ Article 9. 
${ }^{105}$ Ray William London, “Comparative Data Protection and Security Law” p. 139.

106 Signed the ICCPR on 5 October 1998.

${ }^{107}$ Signed the ICCPR on 25 September 2008.

${ }^{108}$ Signed the ICCPR on 28 February 2008.

${ }^{109}$ Signed the ICCPR on 12 November 2001.

${ }^{110}$ Signed the ICCPR on 20 September 2011.

${ }^{111}$ Signed the ICCPR on 22 September 2011.

112 A. C. M. Nugter, Transborder Flow of Personal Data within the EC a Comparative Analysis of Princiepstat Alphen upon Rhine: Kluwer Law Intl 1990, p. 20; Brendan Van Alsenoy, "Regulating Data Protection: The Allocation of Responsibility and Risk among Actors Involved in Personal Data Processing”, PhD Thesis, KU Leuven University, Netherlands, 2016, p. 155.

113 Collin J. Bennett, Regulating Privacy: Data Protection and Public Policy in Europe and the United States, New York: Cornell University Press, 1992, p. 14.

114 Justice Michael D. Kirby, "Transborder Data Flows”, p. 27.

${ }^{115}$ Collin J. Bennett, Regulating Privacy, p. 136.

116 Ibid.

${ }^{117}$ Munir, Yasin, and Karim, Data Protection Law in Asia, p. 39.

118 Justice Michael D. Kirby, "Transborder Data Flows”, p. 27.

${ }^{119}$ Article 5, 9 and 10.

${ }^{120}$ Article 11.

${ }^{121}$ Article 21

122 Mathew Davies, "States of Compliance? Global Human Rights Treaties and ASEAN Member States", Journal of Human Rights, Vol.13, No. 4, 2014, p. 414.

123 "UN Official Welcomes ASEAN Commitment to Human Rights, but Concerned over Declaration Wording", UN News, available athttps://news.un.org/en/story/2012/11/426012\#.UPgVKGckSOI; https://www.amnesty.org/en/documents/ior64/005/2012/en/, accessed 5 September 2019. See also at 'ASEAN leaders adopt lame-duck rights declaration, The Jakarta Post, available at http://www.thejakartapost.com/news/2012/11/19/asean-leaders-adopt-lame-duck-rights-

declaration.html, accessed 14 December 2019; 'Civil Society Denounces Adoption of Flawed ASEAN Human Rights Declaration' Human Rights Watch, available at https://www.hrw.org/news/2012/11/19/civil-society-denounces-adoption-flawed-asean-human-rightsdeclaration, accessed 14 December 2019; 'ASEAN Declaration on Human Rights' U.S. Department of State, available at https://2009-2017.state.gov/r/pa/prs/ps/2012/11/200915.htm, accessed 14 December 2019.

${ }^{124}$ Joel Ng, "ASEAN Human Rights Declaration: A Pragmatic Compromise (RSIS Commentaries, No. 211)", RSIS Commentaries, Nanyang Technological University, Singapore, 2012, p 1.

125 AHRD Booklet, ASEAN Human Rights Declaration, available at https://www.asean.org/storage/images/ASEAN_RTK_2014/6_AHRD_Booklet.pdf, accessed 5 September 2019.

${ }^{126}$ Abraham L. Newman, "Creating Privacy: The International Politics of Personal Information”, PhD Thesis, University of California, Berkeley, the USA, 2005, p. 4.

${ }^{127}$ Brendan Van Alsenoy, "Regulating Data Protection", p. 103.

128 Section 1 and 2 of article 8 of the European Convention on Human Rights and Fundamental Freedoms, 1950.

${ }^{129}$ Article 1.

130 Alex Hern, "What is GDPR and how will it affect you?", The Guardian, available at https://www.theguardian.com/technology/2018/may/21/what-is-gdpr-and-how-will-it-affect-you, accessed 5 September 2019.

${ }^{131}$ European Parliament and Council, 'EU General Data Protection Regulation (GDPR): Regulation ( EU) 2016/679 of the European Parliament and of the Council of 27 April 2016 on the Protection of Natural Persons with Regard to the Processing of Personal Data and on the Free Movement of such Data, and Repealing Directive 95/46/Ec (General Data Protection Regulation), L 119/1, Official Journal of the European Union (2016), article 3 (1).

132 The European Commission, "Countries and Regions", available at https://ec.europa.eu/trade/policy/countries-and-regions/countries/malaysia/, accessed 5 September 2019.

133 GDPR, article 45.

134 The European Commission, “Adequacy Decisions”, available at https://ec.europa.eu/info/law/lawtopic/data-protection/international-dimension-data-protection/adequacy-decisions_en, accessed 5 September 2019.

${ }^{135}$ Information Commissioner's Office, "International Transfers”, available at https://ico.org.uk/for- 
organisations/guide-to-data-protection/guide-to-the-general-data-protection-regulationgdpr/international-transfers\#adequacy-decision, accessed 5 September 2019.

${ }^{136}$ Graham Greenleaf, "Limitations of Malaysia's Data Protection Bill”, Privacy Laws \& Business International Newsletter, Vol. 104, No. 1, 2010, pp. 5-7.

137 The Commission Nationale De L'informatique Et Des Libertés (CNIL), Data Protection around the World, available at https://www.cnil.fr/en/data-protection-around-the-world, accessed 5 September 2019.

138 PDPA, section 3 (1) (2).

${ }^{139}$ Ibid., section 2 (1).

140 GDPR, article 33 (1) and recital 85.

${ }^{141}$ Ibid., article 17 and recitals 65 and 66

${ }^{142}$ Ibid., articles 8, 11, 25 to 39; 41 (4), 42 and 43.

${ }^{143}$ Ibid., articles 5,6,7,9; 12 to $22 ; 44$ to 49 , and 58 (2).

144 Ibid., article 83 and 84 .

145 PDPA, section 113 (7).

146 Ibid., section 16 (4), 18 (4) and 130 (7).

${ }^{147}$ GDPR, article 4 (5).

${ }^{148}$ Ibid., article 4 (5) and 32. 